\title{
HG-CONTAMINATED TERRESTRIAL SPIDERS POSE A POTENTIAL RISK TO SONGBIRDS AT CADDO LAKE (TEXAS/LOUISIANA, USA)
}

\author{
Gretchen L. Gann, $†$ Cleveland H. Powell, $\ddagger$ Matthew M. Chumchal, ${ }^{*} \dagger$ and Ray W. Drenner $\dagger$ \\ $\nmid$ Biology Department, Texas Christian University, Fort Worth, Texas, USA \\ $\ddagger$ School of Geology, Energy and the Environment, Texas Christian University, Fort Worth, Texas, USA
}

(Submitted 22 July 2014; Returned for Revision 7 August 2014; Accepted 31 October 2014)

\begin{abstract}
Methylmercury ( $\mathrm{MeHg}$ ) is an environmental contaminant that can have adverse effects on wildlife. Because MeHg is produced by bacteria in aquatic ecosystems, studies of $\mathrm{MeHg}$ contamination of food webs historically have focused on aquatic organisms. However, recent studies have shown that terrestrial organisms such as songbirds can be contaminated with $\mathrm{MeHg}$ by feeding on $\mathrm{MeHg}$-contaminated spiders. In the present study, the authors examined the risk that $\mathrm{MeHg}$-contaminated terrestrial long-jawed orb weaver spiders (Tetragnatha sp.) pose to songbirds at Caddo Lake (Texas/Louisiana, USA). Methylmercury concentrations in spiders were significantly different in river, wetland, and open-water habitats. The authors calculated spider-based wildlife values (the minimum spider $\mathrm{MeHg}$ concentrations causing physiologically significant doses in consumers) to assess exposure risks for arachnivorous birds. Methylmercury concentrations in spiders exceeded wildlife values for Carolina chickadee (Poecile carolinensis) nestlings, with the highest risk in the river habitat. The present study indicates that $\mathrm{MeHg}$ concentrations in terrestrial spiders vary with habitat and can pose a threat to small-bodied nestling birds that consume large amounts of spiders at Caddo Lake. This MeHg threat to songbirds may not be unique to Caddo Lake and may extend throughout the southeastern United States. Environ Toxicol Chem 2015;34:303-306. (C) 2014 SETAC
\end{abstract}

Keywords: Terrestrial spider Methylmercury Songbird Caddo Lake

\section{INTRODUCTION}

Methylmercury $(\mathrm{MeHg})$ is an environmental contaminant that can have adverse effects on wildlife [1]. Most mercury (Hg) in the environment originates from anthropogenic sources that release $\mathrm{Hg}$ into the atmosphere [2], but $\mathrm{Hg}$ can also be discharged directly into water bodies from industrial sources [3]. Inorganic $\mathrm{Hg}$ deposited from the atmosphere or discharged from industrial sources into aquatic systems is converted to $\mathrm{MeHg}$ by bacteria [2]. Methylmercury enters the food chain and biomagnifies, reaching high concentrations in predators [4]. Because inorganic $\mathrm{Hg}$ is converted to $\mathrm{MeHg}$ primarily in aquatic ecosystems, studies of $\mathrm{MeHg}$ contamination of food webs historically have focused on aquatic organisms. However, recent studies have found that terrestrial organisms such as songbirds can be contaminated with $\mathrm{MeHg}$ [5-8]. At the South River (VA, USA), a site contaminated by industrial discharge into the river, Cristol et al. [6] found that songbirds could be exposed to $\mathrm{MeHg}$ by feeding on $\mathrm{MeHg}$ contaminated spiders. No studies have investigated whether MeHg-contaminated spiders pose a risk to arachnivorous birds at sites polluted with atmospheric $\mathrm{Hg}$.

In the present study, we examined the risk that MeHg-contaminated terrestrial spiders pose to songbirds at Caddo Lake (TX and LA, USA). Caddo Lake is a large river-wetland-lake complex [9] that is contaminated with $\mathrm{Hg}$ from the atmosphere [10]. Because $\mathrm{MeHg}$ contamination of the food chain in Caddo Lake varies spatially, with highest and lowest levels in the wetland and open-water habitats, respectively [11,12], we hypothesized that $\mathrm{MeHg}$ contamination of terrestrial spiders and the risk they pose to birds would vary between

All Supplemental Data may be found in the online version of this article.

* Address correspondence to m.m.chumchal@tcu.edu

Published online 5 November 2014 in Wiley Online Library (wileyonlinelibrary.com).

DOI: $10.1002 /$ etc. 2796 habitats. To test this hypothesis, we collected long-jawed orb weaver spiders (Tetragnatha sp.) from different habitats of Caddo Lake and determined if the $\mathrm{MeHg}$ concentrations in these spiders were high enough to pose a risk to songbirds. Long-jawed orb weaver spiders are predators that can become contaminated with high concentrations of $\mathrm{MeHg}$ by feeding on small-bodied emergent aquatic insects such as chironomids $[13,14]$. Several investigators have proposed using the long-jawed orb weaver spider as an indicator species for monitoring sites polluted with biomagnifying contaminants (e.g., polychlorinated biphenyls, MeHg) $[13,15,16]$.

\section{METHODS}

\section{Study site}

Caddo Lake and its associated wetlands are located on the border of Texas and Louisiana and cover 10850 hectares [9]. The western portion of the lake is a relatively shallow forested wetland dominated by bald cypress (Taxodium distichum) and water elm (Planera aquatica) [17], and it receives riverine inflows from Big Cypress Bayou. The eastern portion of the lake is primarily open-water habitat [18]. Forested wetlands with diverse habitat types (e.g., river, wetland, and open-water habitats) such as Caddo Lake occur throughout the southeastern United States [19].

Elevated concentrations of $\mathrm{Hg}$ have been found in aquatic invertebrates, fish, snakes, and piscivorous birds from Caddo Lake [11,12,20-24]. Mercury contamination in Caddo Lake is of particular concern because the lake supports a high level of biodiversity, including rare and threatened species [9], which may be negatively impacted by $\mathrm{MeHg}$ exposure [23].

\section{Spider collection}

Spiders were collected from 56 sites $(n=17,22$, and 17 sites from river, wetland, and open-water habitats, respectively) from 
20 May to 19 June 2013 (Supplemental Data, Figure S1). Individual spiders were collected from trees, emergent aquatic vegetation, and docks with nets and by hand and immediately preserved in $95 \%$ nondenatured ethanol. We collected $14.0 \pm 6.9$ (average \pm standard deviation) spiders at each sampling site. Prior to $\mathrm{Hg}$ analysis, spiders were dried at $60{ }^{\circ} \mathrm{C}$ for $48 \mathrm{~h}$ and homogenized to a fine powder using a ballmill grinder.

\section{Hg analysis}

We determined total $\mathrm{Hg}$ concentrations in composite samples of spiders from each site using a Milestone Direct $\mathrm{Hg}$ Analyzer, which uses thermal decomposition, gold amalgamation, and atomic absorption spectroscopy [25]. Quality assurance included reference (National Research Council of Canada Institute for National Measurement Standards) and duplicate samples. Reference samples (DORM-2) were analyzed approximately every 10 samples, and the average percentage of recovery was $101 \pm 1.48 \%$ (range, 99.3-104\%; $n=27$ ). Duplicate samples were analyzed approximately every 20 samples, and the average relative percent difference was $1.68 \pm 1.55 \%$ (range, $0.07-5.95 \% ; n=18$ ). The limit of detection was $0.39 \mathrm{ng}$ of $\mathrm{Hg}$ (i.e., $13 \mathrm{ng} / \mathrm{g}$ based on a typical sample weight of $0.03 \mathrm{~g}$ ). All samples were above the limit of detection.

We estimated $\mathrm{MeHg}$ concentrations in spiders from total $\mathrm{Hg}$. Using data collected in conjunction with a previous study [13], we determined that $70.8 \%$ of total $\mathrm{Hg}$ (inorganic $\mathrm{Hg}+\mathrm{MeHg}$ ) in long-jawed orb weaver spiders was $\mathrm{MeHg}$ (Supplemental Data). In the present study, total $\mathrm{Hg}$ was converted to $\mathrm{MeHg}$ by multiplying total $\mathrm{Hg}$ by 0.708 .

In the present study, $\mathrm{MeHg}$ data are presented on a wet weight basis. Total $\mathrm{Hg}$ concentrations were initially determined on dried spider tissue. Using a supplemental sample of long-jawed orb weaver spiders, we determined that water accounts for $69.4 \%$ of the body weight of spiders (Supplemental Data). Therefore, we estimated wet weight $\mathrm{MeHg}$ concentrations by dividing dry weight $\mathrm{MeHg}$ concentrations by a conversion factor of 3.27 to account for weight change as a result of water loss.

\section{Method for calculating spider-based avian wildlife values for $\mathrm{MeHg}$ and risk to songbirds}

Spider-based avian wildlife values were calculated to assess the exposure risk for arachnivorous birds at Caddo Lake using methods modified from the US Environmental Protection Agency (USEPA) [26], Lazorchak et al. [27], and Walters et al. [15] (Supplemental Data). Spider-based avian wildlife values reflect the minimum $\mathrm{MeHg}$ concentrations in spiders, consumed by birds in normal proportions of total diet, required to create physiologically significant doses $[15,26]$. A lower wildlife value is associated with a higher sensitivity of birds to consumption of $\mathrm{MeHg}$-contaminated spiders [15].

Wildlife values were developed for 1-d-old and 12-d-old Carolina chickadees (Poecile carolinensis) and adult Carolina wrens (Thryothorus ludovicianus), eastern bluebirds (Sialia sialis), and American robins (Turdus migratorius). We used these 4 species of birds because they are year-round residents of the Caddo Lake region [28], and Walters et al. [15] presented life-history data that we could use to compute their wildlife values (Supplemental Data, Table S1). These species could be considered surrogates for other small passerine birds with similar levels of spider consumption and ingestion rates.

Following the approach of Walters et al. [15], we compared avian wildlife values with spider $\mathrm{MeHg}$ concentrations to assess the relative risk to birds consuming spiders. In the present study, long-jawed orb weaver spiders were used as a proxy for all spider taxa consumed by birds. During the present study we observed 2 species of songbirds feeding on long-jawed orb weaver spiders, and other studies have documented that longjawed orb weavers are consumed by birds [29-31]. We assessed risk to birds by calculating a risk quotient as spider concentration/avian wildlife value. The risk quotient represents the proportional difference between dietary concentrations and those expected to cause adverse effects in birds [15]. Spider $\mathrm{MeHg}$ concentrations exceed avian wildlife values when the risk quotient is $>1$. Risk quotients were calculated at each sampling site and averaged for river, wetland, and open-water habitats for each bird species.

There are a number of sources of uncertainty in this screening-level risk analysis. For example, we did not consider bird movement between habitats or foraging outside of the areas surrounding Caddo Lake. In addition, birds may consume a variety of spider taxa, with different concentrations of $\mathrm{MeHg}$ from those in long-jawed orb weavers. Finally, birds may consume emergent aquatic insects, which would also be contaminated with $\mathrm{MeHg}$; and this source of dietary $\mathrm{MeHg}$ was not considered in the present risk analysis.

\section{Statistical analysis}

To determine if spider $\mathrm{MeHg}$ concentrations differed among habitats, we used a one-way analysis of variance (ANOVA), followed by a Tukey post hoc test. Following guidelines of the USEPA [32], we used a modified $t$ test to determine if the average $\mathrm{MeHg}$ concentration of spiders within a habitat was significantly greater than the calculated wildlife value for each bird species (i.e., if the risk quotient was significantly $>1$ ).

\section{RESULTS AND DISCUSSION}

Site-specific $\mathrm{MeHg}$ concentrations in spiders ranged from $19.4 \mathrm{ng} / \mathrm{g}$ wet weight to $256 \mathrm{ng} / \mathrm{g}$ wet weight, with a longitudinal trend of decreasing $\mathrm{MeHg}$ concentrations from west to east across Caddo Lake (Figure 1). Methylmercury concentrations in spiders were significantly different among habitats, with highest to lowest concentrations found in the river $(150 \pm 47 \mathrm{ng} / \mathrm{g})$, wetland $(115 \pm 37 \mathrm{ng} / \mathrm{g})$, and open-water $(63 \pm 22 \mathrm{ng} / \mathrm{g}) \mathrm{hab}$ itats, respectively (ANOVA, $F_{2,53}=24.1, p<0.001$; Tukey, $p$ $<0.05$ for all habitat comparisons; Figure 1).

Wildlife values for $\mathrm{MeHg}$ in songbirds, expressed as nanograms of $\mathrm{MeHg}$ per gram of spider tissue per day, were 34.6 ng/g/d (12-d-old Carolina chickadee), $52.0 \mathrm{ng} / \mathrm{g} / \mathrm{d}$ (1-d-old Carolina chickadee), $175 \mathrm{ng} / \mathrm{g} / \mathrm{d}$ (Carolina wren), $281 \mathrm{ng} / \mathrm{g} / \mathrm{d}$ (eastern bluebird), and $433 \mathrm{ng} / \mathrm{g} / \mathrm{d}$ (American robin). Carolina chickadee nestlings were the most sensitive to $\mathrm{MeHg}$ contaminated spiders because they are small-bodied and have high consumption rates of spiders (Supplemental Data, Table S1). Conversely, Carolina wrens, eastern bluebirds, and American robins were less sensitive to $\mathrm{MeHg}$-contaminated spiders because they are large-bodied and/or have low consumption rates of spiders (Supplemental Data, Table S1).

For each bird species, the risk quotient was greatest in the river, followed by the wetland and open-water habitats (Figure 2). Only 12-d-old and 1-d-old Carolina chickadees had risk quotients that exceeded 1 , indicating that they are at risk from consuming spiders at Caddo Lake. The 12-d-old and 1-dold Carolina chickadees were at risk in all 3 habitats (Figure 2). Average risk quotients of Carolina chickadees across habitats ranged from 1.22 to 4.34 , indicating that spider consumption at 


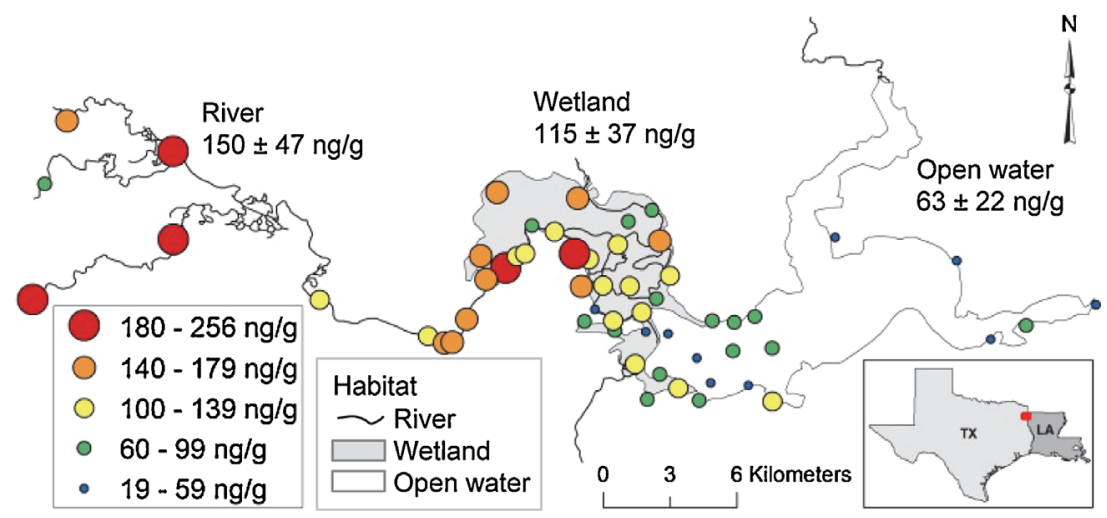

Figure 1. Site-specific concentrations of methylmercury (wet) in long-jawed orb weaver spiders at Caddo Lake. Average ( \pm standard deviation) concentrations of methylmercury in spiders from each of the 3 habitats are presented.

Caddo Lake would result in $\mathrm{Hg}$ exposures ranging from $122 \%$ to $434 \%$ of wildlife values.

The present study is one of the first to find that $\mathrm{MeHg}$ accumulation in terrestrial spiders poses a potential risk to arachnivorous songbirds, like nestling Carolina chickadees, at a site contaminated with $\mathrm{Hg}$ from the atmosphere. We also found that $\mathrm{MeHg}$ in spiders and bird risk varied across Caddo Lake, with the highest concentrations of $\mathrm{MeHg}$ in spiders and the greatest risk to birds in the river habitat. Our risk-analysis approach is a critical first step for identifying at-risk populations of sensitive species and life stages [15] and suggests that $\mathrm{MeHg}$ poses a risk to songbirds at Caddo Lake.

It is likely that this $\mathrm{MeHg}$ threat to songbirds is not unique to Caddo Lake and that it may extend throughout the southeastern United States. Long-jawed orb weaver spiders [33] and arachnivorous songbirds [28] are found throughout the southeastern United States. In addition, the environmental factors that led to $\mathrm{MeHg}$ contamination of Caddo Lake's food chain, such as high levels of atmospheric $\mathrm{Hg}$ deposition [34] and forested-wetland habitats [35], are common throughout the southeastern United States. Evaluating spider $\mathrm{MeHg}$ concentrations within a risk framework, as in the present study, may be a cost-effective way to identify water bodies with high levels of

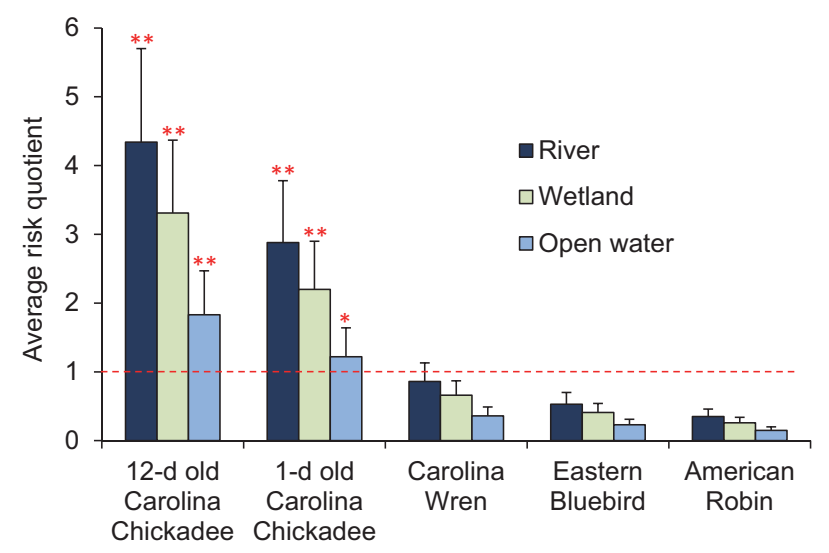

Figure 2. Average ( \pm standard deviation) risk quotients for river, wetland, and open-water habitats for 5 birds. A risk quotient of 1 (indicated by dashed red line) indicates the point at which methylmercury concentrations in spiders are equivalent to the avian wildlife value. A risk quotient significantly $>1$ (indicated by asterisks) indicates that birds are at risk from consuming methylmercury-contaminated spiders ( $t$ test: $* p<0.025$; $* * p<0.001)$
$\mathrm{Hg}$ contamination and populations of songbirds at risk [15] in the southeastern United States.

In general, the assessment of MeHg's threat to songbirds is just beginning to be understood [36]. Successful bird conservation strategies are dependent on a comprehensive understanding of the threats to populations [36]. An increasing body of literature suggests that elevated amounts of $\mathrm{MeHg}$ in the diet can pose a risk to songbirds (e.g., Jackson et al. [37] and Varian-Ramos et al. [38]). The present study suggests that songbirds that consume long-jawed orb weaver spiders at sites contaminated with $\mathrm{Hg}$ from the atmosphere will be exposed to aquatic $\mathrm{MeHg}$ pollution and that nestling arachnivorous songbirds are most at risk. Given that songbirds are critical components of ecosystems [39] and are economically important because of birding [40], $\mathrm{MeHg}$ accumulation in these species may have a negative effect on the ecology and economy of this region.

\section{SUPPLEMENTAL DATA}

Table S1.

Figure S1. (158 KB DOC).

Acknowledgment-We thank K. Adams, V. Adams, P. Drevnick, T. Morgan, C. Eagles-Smith, D. Renkenberger, and J. Roesner. The Caddo Lake National Wildlife Refuge provided housing during the study. The present research was supported by a Texas Christian University Research and Creative Activities Fund Grant and the Texas Christian University Biology Department's Adkin's Fund.

\section{REFERENCES}

1. Wiener JG. 2013. Mercury exposed: Advances in environmental analysis and ecotoxicology of a highly toxic metal. Environ Toxicol Chem 32:2175-2178.

2. Selin NE. 2009. Global biogeochemical cycling of mercury: A review. Ann Rev Environ Res 34:43-63.

3. Carter LJ. 1977. Chemical plants leave unexpected legacy for two Virginia rivers. Science 198:1015-1020.

4. Lavoie RA, Jardine TD, Chumchal MM, Kidd KA, Campbell LM. 2013. Biomagnification of mercury in aquatic food webs: A worldwide meta-analysis. Environ Sci Technol 47:13385-13394.

5. Edmonds ST, Evers DC, Cristol DA, Mettke-Hofmann C, Powell LL, McGann AJ, Armiger JW, Lane OP, Tessler DF, Newell P. 2010. Geographic and seasonal variation in mercury exposure of the declining rusty blackbird. Condor 112:789-799.

6. Cristol DA, Brasso RL, Condon AM, Fovargue RE, Friedman SL, Hallinger KK, Monroe AP, White AE. 2008. The movement of aquatic mercury through terrestrial food webs. Science 320:335.

7. Brasso RL, Cristol DA. 2008. Effects of mercury exposure on the reproductive success of tree swallows (Tachycineta bicolor). Ecotoxicology 17:133-141. 
8. Jackson AK, Evers DC, Folsom SB, Condon AM, Diener J, Goodrick LF, McGann AJ, Schmerfeld J, Cristol DA. 2011. Mercury exposure in terrestrial birds far downstream of an historical point source. Environ Pollut 159:3302-3308.

9. Ingold JL, Hardy LM. 1996. Web of Life: The Ecology and Biodiversity of Caddo Lake. Louisiana State University, Shreveport, LA, USA.

10. Twidwell S, 2000. Bioaccumulation of mercury in selected east Texas water bodies. AS-180. Texas Commission on Environmental Quality, Austin, TX, USA.

11. Chumchal MM, Hambright KD. 2009. Ecological factors regulating mercury contamination of fish from Caddo Lake, Texas, USA. Environ Toxicol Chem 28:962-972.

12. Chumchal MM, Drenner RW, Fry B, Hambright KD, Newland LW. 2008. Habitat-specific differences in mercury concentration in a top predator from a shallow lake. Trans Am Fish Soc 137:195-208.

13. Tweedy BN, Drenner RW, Chumchal MM, Kennedy JH. 2013. Effects of fish on emergent insect-mediated flux of methyl mercury across a gradient of contamination. Environ Sci Technol 47:1614-1619.

14. Speir SL, Chumchal MM, Drenner RW, Cocke WG, Lewis ME, Whitt HJ. 2014. Methyl mercury and stable isotopes of nitrogen reveal that a terrestrial spider has a diet of emergent aquatic insects. Environ Toxicol Chem 33:2506-2509.

15. Walters DM, Mills MA, Fritz KM, Raikow DF. 2010. Spider-mediated flux of PCBs from contaminated sediments to terrestrial ecosystems and potential risks to arachnivorous birds. Environ Sci Technol 44:2849 2856.

16. Otter RR, Hayden M, Mathews T, Fortner A, Bailey FC. 2013. The use of tetragnathid spiders as bioindicators of metal exposure at a coal ash spill site. Environ Toxicol Chem 32:2065-2068.

17. Van Kley JE, Hine DN. 1998. The wetland vegetation of Caddo Lake. Tex J Sci 50:267-290.

18. Ensminger PA.1999. Bathymetric survey and physical and chemicalrelated properties of Caddo Lake, Louisiana and Texas, August and September 1998. Water-Resources Investigations Report 99-4217. US Geological Survey, Denver, CO.

19. Conner WH, Buford MA. 1998. Southern deepwater swamps. In: Messina MG, Conner WH, eds, Southern Forested Wetlands Ecology and Management. Lewis,Boca Raton, FL, USA: pp 261-287.

20. Giggleman CM, Baker DM, Lusk JD. 1998. A contaminants survey of three lentic systems within the Cypress Creek Watershed, Texas, 19931995. 9320005/2F27. US Fish and Wildlife Service, Region 2, Arlington Ecological Services Field Office, Arlington, TX.

21. Rainwater TR, Reynolds KD, Canas JE, Cobb GP, Anderson TA, McMurry ST, Smith PN. 2005. Organochlorine pesticides and mercury in cottonmouths (Agkistrodon piscivorus) from northeastern Texas, USA. Environ Toxicol Chem 24:665-673.

22. Chumchal MM, Rainwater TR, Osborn SC, Roberts AP, Abel MT, Cobb GP, Smith PN, Bailey FC. 2011. Mercury speciation and biomagnification in the food web of Caddo Lake, Texas and Louisiana, USA, a subtropical freshwater ecosystem. Environ Toxicol Chem 30:1153-1162.

23. Barst BD, Gevertz AK, Chumchal MM, Smith JD, Rainwater TR, Drevnick PE, Hudelson KE, Hart A, Verbeck GF, Roberts AP. 2011. Laser ablation ICP-MS co-localization of mercury and immune response in fish. Environ Sci Technol 45:8982-8988.
24. Chumchal MM, Drenner RW, Cross DR, Hambright KD. 2010. Factors influencing mercury accumulation in three species of forage fish from Caddo Lake, Texas, USA. J Environ Sci 22:1158-1163.

25. US Environmental Protection Agency. 1998. Method 7473: Mercury in solids and solutions by thermal decomposition, amalgamation, and atomic absorption spectrophotometry. Washington, DC.

26. US Environmental Protection Agency. 1995. Great Lakes water quality initiative: Criteria documents for the protection of wildlife-DDT, mercury, 2,3,7,8-TCDD, PCBs. EPA 820/B-95/008. Washington, DC.

27. Lazorchak JM, McCormick FH, Henry TR, Herlihy AT. 2003. Contamination of fish in streams of the mid-Atlantic region: An approach to regional indicator selection and wildlife assessment. Environ Toxicol Chem 22:545-553.

28. Poole A. 2005. The Birds of North America. Ithaca (NY, USA): Cornell Lab of Ornithology. [cited 2014 July 22]. Available from: http://bna. birds.cornell.edu/bna/

29. Chapin EA. 1925. Food habits of the vireos: A family of insectivorous birds. Bulletin No. 1355. US Department of Agriculture, Washington, DC.

30. Van Houtan KS, Alvarez-Loayza P. 2006. Diet of nestling green-andgold tanagers (Tangara schrankii), with notes on nesting behavior and seed dispersal. Ornitol Neotrop 17:307-312.

31. Kopec AD, Bodaly RA. 2013. Analysis of aquatic and wetland food webs in the Penobscot estuary. Penobscot River Mercury Study. [cited 2014 October 30]. Available from: http://www.maine.gov/dep/spills/ holtrachem/penobriver/final/Chapter\%2016.pdf.

32. US Environmental Protection Agency. 2000. Guidance for assessing chemical contaminant data for use in fish advisories. EPA 823/B-00/ 007. Washington, DC.

33. Levi HW. 1981. American orb-weaver genera Dolichognatha and Tetragnatha north of Mexico (Araneae: Araneidae, Tetragnathinae). Bull Mus Comp Zool 149:271-318.

34. National Atmospheric Deposition Program. Mercury Deposition Network Data. [cited 2014 July 22]. Available from: http://nadp.sws. uiuc.edu/mdn/

35. Multi-Resolution Land Characteristics Consortium. National Land Cover Database.[cited 2014 July 22]. Available from: http://www.mrlc. gov/index.php.

36. Seewagen CL. 2010. Threats of environmental mercury to birds Knowledge gaps and priorities for future research. Bird Conserv Int 20:112-123.

37. Jackson AK, Evers DC, Etterson MA, Condon AM, Folsom SB Detweiler J, Schmerfeld J, Cristol DA. 2011. Mercury exposure affects the reproductive success of a free-living terrestrial songbird, the Carolina wren (Thryothorus ludovicianus). Auk 128:759-769.

38. Varian-Ramos C, Swaddle JP, Cristol DA. 2014. Mercury reduces avian reproductive success and imposes selection: An experimental study with adult- or lifetime-exposure in zebra finch. PLOS ONE 9:-e 95674.

39. Whelan CJ, Wenny DG, Marquis RJ. 2008. Ecosystem services provided by birds. Ann N Y Acad Sci 1134:25-60.

40. Carver E. 2009. Birding in the United States: A demographic and economic analysis. Addendum to the 2006 National Survey of Fishing, Hunting, and Wildlife-Associated Recreation. US Fish and Wildlife Service, Arlington, VA. 